Mr. Stanley does not exaggerate the importance of this discovery. That the river has any connection with Tanganyika is in the highest degree improbable, as the Victoria into which it drains is more than 500 feet above the level of Tanganyika ; but the question of the connections of this lake Mr. Stanley, we hope, has by this time solved. He afterwards traced the Kagera upwards in a south and west direction, the direction in which trend all the ranges in this region, as, indeed, run all the great ridges, troughs, basins, and valleys from Alexandria to the Nyassa Lakes. In Southern Kishakka, however, a valley struck in from the north-west, through which he found issuing into the Kagera, a large lake-like river called Akanyaru. Above the confluence the Kagera was seen to be a swift-flowing stream of no great depth or breadth. From the Mlagata hot springs Stanley obtained a good view of the region to the north-west, including the Ufumbiro mountains, two sugar-loaf cones and a ridge-like mass, reaching a height of 12,000 feet. From this point of view, also, he saw three other lofty ridges separated by broad valleys. Between two of these ridges flows the Nawarongo river rising in the Ufumbiro mountains, and flowing south by west to join the Akanyaru lake-river. Another large lake he heard of as lying to the westwards, but of this he could obtain no certain information.

Of Stanley's visit to Lake Albert Nyanza little need at present be said, as he succeeded in obtaining only a glimpse of it, when he felt himself compelled to return. Some important observations, however, he did succeed in making, and collected many scraps of information. His statements about "the king of mountains," Gambaragara, and its pale-faced, brown-haired inhabitants, the chief medicine-men of the notorious Kabba Rega, have roused curiosity to the utmost. This mountain, which appears to be situated somewhere on the north of Unyampaka, in height between 13,000 and 15,000 feet, Mr. Stanley conjectures to be an extinct volcano, as "on the top of it is a crystal-clear lake, about 500 yards in length, from the centre of which rises a column-like rock to a great height. A rim of stone like a wall surrounds the summit, within which are several villages, where the principal medicine-man and his people reside." Stanley's route to the Albert Lake was partly through Unyoro and partly through an uninhabited tract of Ankori, his camp being pitched near the edge of the plateau which borders the lake, in the district of Unyampaka. During his march he made important observations on the contour of the plateau which separates the two lakes, the structure of the mountains and ridges, the course of the watersheds and of the rivers Katonga and Rusango. The general correctness of Baker's map, so far as the east coast is concerned, has been confirmed, and although the actual lake may not extend south of the equator, it is probable that there are long stretches of papyrus swamps at its head. The kingdom of Unyoro, under Kabba Rega, occupies a large extent of the eastern shore of the lake, and includes many minor states, the names of which, and of others on the west side, Mr. Stanley succeeded in collecting. The extensive promontory of Usongora, forming Beatrice Gulf, on the shores of which Mr. Stanley encamped, is the great saltfield whence all the surrounding countries obtain their salt, and rumour makes it a land of wonders, with a mountain emitting fire and stones, a salt lake of great extent, hills of salt, and a breed of large savage dogs and longlegged natives. Mr. Stanley gives the latitude of his camp on Lake Albert as $0^{\circ} 25^{\prime} \mathrm{N}$. and longitude $31^{\circ} 24^{\prime} 30^{\prime \prime} \mathrm{E}$. It is difficult to reconcile this last datum with previous observations, and indeed with the length of Stanley's own march between the two lakes. If his own map of Victoria is correct, the two lakes must be within thirty miles of each other. It is probable, we believe, that Sir Samuel Baker's map places the east coast of the lake too far west, and that its position will have ultimately to be changed, but if to so great an extent as is indicated by Stanley's statement, must be solved by further observations. At present we cannot reconcile Signor Gessi's narrative with that of Stanley. Gessi states that he was stopped in his navigation by a "forest of Ambatch," some thirty miles to the north of Stanley's Beatrice Gulf, and that the natives declared the lake extended no farther south. The statements of the two travellers are equally positive, and we have no reason to distrust either, and therefore we can only wait for more information, which, it is likely, will now soon reach us, either from Mr. Stanley or Mr. Lucas, an independent traveller, who is actuated purely by a love of exploration, and who, by last accounts, was on his way to the lake.

On his return from this expedition Mr. Stanley set out southwards through Karagwe for Ujiji, his purpose being, if possible. to reach Lake Albert from the west and make as thorough an exploration of it as he has done of the Victoria Lake. The chances are that he will be successful. It was while in Karagwe that, by the assistance of the hospitable old king Rumanika, he was able to explore the Kagera lacustrine region. On completing this exploration he visited the hot springs of Mlagata, two days' march from Rumanika's capital, in a deep-wooded gorge clothed in the most luxuriant vegetation. These springs reach a temperature of about $130^{\circ} \mathrm{Fahr}$., and are greatly resorted to for their supposed curative effects, which $\mathrm{Mr}$. Stanley seems to doubt.

Mr. Stanley's last letter is dated April 24, I876, from Ubagwe, Western Unyamwezi, fifteen days' journey from Ujiji, which, if all has gone well, he will have reached long ago. Before setting out for Lake Albert again, he proposed to explore the hitherto unvisited portion of the north-west shore of Tanganyika. From this exploration some authorities expect important results to follow; it is indeed thought possible that in this direction will be found the real outlet of Tanganyika, and that Cameron's river Lukuga may ultimately be discovered to be after all only an indentation of the lake, and that moreover a connection will be found between Tanganyika and the Albert Nyanza. However this may be, both explorers have done work of the highest importance in African geography, and the last published letters of Stanley must be regarded as a really valuable contribution to the solution of the great Nile problem and to an accurate knowledge of Central Africa. He has proved himself an explorer of the greatest capability, and the expedition he leads reflects credit on the enterprise and public spirit of the proprietors of the two newspapers who have sent him out.

\section{COFFEE IN CEYLON}

CEYLON is perhaps best known to Europeans through being one of the chief coffee-growing countries in the world, and indeed, after its production of cinnamon, which gives it a position that is quite unique, its chief claims to notice from the ordinary untravelled Englishman are derived from its coffee. The plant is supposed to have been introduced into the island by Arabs from the Pexsian Gulf more than 200 years ago, as there are traditions extant among the Singhalese of its flowers having been offered at the shrine of the sacred tooth of Buddha in Kandy at a remote date. The art, however, of preparing any beverage from its berries was unknown to the natives, or at least unpractised by them until recent times, and it was only in 1827 that the first plantation was opened--by Sir Edward Barnes, the then Governorwith the idea of exporting coffee to the European market. This estate was situated not far from Kandy, and at an elevation of some 1,800 feet above the sea. Thirteen years afterwards the first rush of speculators in coffee occurred, when the average quantity exported was 54,000 
cwts., and its value about $150,000 \%$. The effect of this sudden impulse to the enterprise was seen six years afterwards, in 1846 , in the export rising to 178,000 cwts. In I 855 it was close upon half-a-million, and in 1868 somewhat over a million cwts., valued at the low rate of about $50 s$, per cwt, and grown on an area, including native coffee gardens, of about 200,000 acres. In the following year "leaf disease" (Hemileia vastatrix), a species of fungus covering the under surface of the coffee-leaf with an orange-red coloured dust composed of the ripe spores of the fungus, appeared on a newly-opened estate in Madulsima, and within a very short time spread over all the coffee-producing districts in the island. The ravages of the pest have been so great that the annual production of coffee has been reduced to less than two-thirds of what it ought to have been, and the loss to the colony can only be estimated at many millions of pounds sterling. But this subject will be referred to later ; at present we must attempt to give some idea of the character of the country in which the great staple of the island grows. Ceylon, as is pretty generally known, consists, roughly speaking, of a large central mass of mountains, attaining an elevation in one case of more than 8,000 feet, and surrounded on all sides by low country. This mountain region, as well as the low country, is composed almost entirely of primary rock (gneiss), and bears such a striking resemblance to the Western Ghaut Range of Southern India, that the island may be considered as an isolated portion of that continent, separated, perhaps, Huring the upheaval of both by the strong monsoon currents that set continually along the coasts of India, according as the sun is north or south of the line. It is not improbable that other stratified rocks have once overlaid the ancient gneiss, but no rock less tough could long withstand the torrential rains of the south-west monsoon and the injurious effects of a tropical sun. If any such have formerly existed, every trace of them has long ago been washed down to the low country or the sea. It is true that at one spot on the western coast, apparently protected from the violence of the monsoon rains, and where, consequently, the rainfall is very slight, the remnant of a fossiliferous limestone of very limited extent is to be met with, but this, I believe, is the one solitary exception, and its relation to the gneiss formation of the rest of the island and to the coast of Southern India, has not, $I$ imagine, been sufficiently explained. At the present time the soil of Ceylon is formed exclusively by the disintegration of zneiss rock, the débris of which settles in protected spots and on slopes not too steep for its accumulation. In its natural state it is nearly always very strongly tinged with red, and to an ordinary observer appears to be of a very poor character. This no doubt is really the case, but it affords standing-ground for trees and other forms of vegetable life, and a forcing climate does the rest. With a rainfall over the greater part of the mountain zone of more than 100 inches, in some places more than 200 inches in the year, distributed chiefly between the middle of May and the end of December and with such a rapid descent from the upper mountain slopes to the low country-the great river of the island, the Mahawellisanga, descends at the average rate of ninety feet per mile for the first sixty or seventy miles of its course-it was only to be expected that extremely deep valleys, steep slopes and precipices, and a general waterworn aspect should be met with on every side. These features are so marked throughout the coffee-producing districts, that it is by no means unusual to find the upper portion of a block of 300 acres some 1,800 or 2,000 feet above the lower, and the whole estate nothing more than a series of rounded spurs and deep ravines, with here and there a precipice of considerable height, with an accumulation of rocks about its base. It is at the foot of these cliffs that the best soil for any purpose of cultivation is found, whilst the worst is generally on the most exposed parts of the spurs. This is no doubt due to the accumulatinn of vegetable mould, and the nutritive properties of the decaying rocks, which is possible in the one case, but not in the other, to any great extent. It is to the former of these substances, to the result of ages of forest growth and decay, that coffee estates owe their chief value; without it they are almost worthless, as may be seen in the case of old estates, whose surface-soil has been washed away through want of drainage or on the grassy slopes of patanas, where jungle has never grown, and where of course there is no humus. On either it is next to impossible to grow coffee profitably. As these patanas or patches of poor grass land in the midst of luxuriant forest form one of the most striking features of the mountain scenery of Ceylon, and as no satisfactory explanation has as yet been given of them, it may be well to mention that a band of quartzite (metamorphosed sandstone) several hundred feet in thickness, occupies a definite place in the gneiss series of the mountain zone, and that wherever this is found cropping out, and by its disintegration forming the surface-soil, there we are certain to find the ground of such miserable quality that nothing but a coarse and all but worthless grass will grow. This, however, does not fully explain the phenomenon. It may be noticed as against the theory that these patanas are due to the frequent burnings by the natives after the land has once been cleared of jungle, and then allowed to fall into grass, that, however land that has once been jungle may be exhausted by bad cultivation, its tendency is not to run into grass, but to relapse into a kind of scrub, and thence in time into jungle-a tendency which is never seen in patana land. The best estates, the climates being similar, are where the humus is deepest, or where its constituents have been carried furthest by percolation into a friable soil. The protection of this humus and upper soil is the first and most important duty of the planter on a new estate, and the drainage, therefore, at the outset, is rendered as complete as possible.

An idea of the rate at which the surface soil even of old and well-worn estates is carried away, may be formed from the fact that $\frac{7}{5}$ th part by weight of the surfacewater passing down a stream in Pussellawa-one of the oldest and best coffee districts--after a heavy shower was found by the writer to be earthy matter ; a startling observation indeed, but one that fairly agrees with an estimate made, after considerable experience, that one of the abovementioned old estates had suffered denudation since it was opened more than thirty years ago, at the rate of about one-third of an inch per annum. This is a startling fact and suggests the inquiry, When will the land available for coffee in Ceylon be used out or washed away? It is already nearly all occupied, and it seems that before long, that is, within a score or two of years, in spite of all the exertions of the modern planter, all its fertile properties will be irrecoverably lost. Forest growth and decay have created the wealth of the Kandyan Province, and the ignorant or careless planter of the past has as truly wasted the natural resources of the country as if he had destroyed all its coco-nut trees, only in the one case the evil would be temporary--twenty years would repair it; in the other ten times that period of absolute rest would probably not restore the fertility to the mountain slopes and bring them again to the state in which the European found them. Land suitable for coffee lies generally between 2,000 and 5,000 feet above the sea, but the climate of the district and the aspect count for a good deal. Estates from 3,000 to 4,000 feet in altitude are considered the best, the plants then being neither burnt up by the hot sun of lower elevations nor ruined by the blackbug-really a fungus, Capnodiam, thriving on the honeydew secretion of the bug Lecanium Coffex, and often mistaken for it-which is a sure visitor of high and wet estates. An eastern slope is generally preferred, but what effect the early sun produces I have never been able to 
discover-unless it saves the plant to a great degree from the chills of early morning.

As to climate the variety in this respect is most marked. On one side of a small range the coffee exposed to the south-west monsoon is mostly ripe about November. On the opposite side, four miles away, where it is subject to the influence of the north-east rains, it is generally picked three if not four months later, whilst in the most favoured districts in the southern part of the mountain zone where the rainfall is considerably influenced by mountains that lie in the track of the monsoon the crop time lasts through nine months, i.e., from September to May-buds, flowers, green and ripe fruit, being on the tree all at the same time.

Young plants are generally put into the ground soon after the rainy season has commenced, stumps being used in the southern part of the province and where the weather is uncertain. Under the influence of a plentiful supply of moisture and an average temperature of $70^{\circ}$ to $75^{\circ} \mathrm{F}$., the roots scon strike and the tree grows so rapidly, that at the end of two years a small quantity of fruit may sometimes be gathered. In its fourth year the tree bears a good crop, and two years later it may be considered to be in its prime. About 1,200 to 1,600 are generally planted on an acre, and each tree, when it attains a height of four or five feet, is cut down to $3 \mathrm{ft}$. 6 ins, and even lower in exposed places and on poor soil, according to the taste of the planter. The lateral branches are kept most carefully pruned, and the tree thus cared for forms a cylindrical mass of foliage into the centre of which the sun's heat can penetrate and ripen the fruit. The trees are planted six feet by five feet or six feet apart, and when fully grown in good soil, present a mass of intervening branches through which it is somewhat difficult to make one's way. When an estate has attained an age of twenty years it is considered to be well past its prime, and only to be kept profitable by means of a plentiful supply of manure, and indeed the main question with planters now is not so much how to treat the tree itself, but how to obtain good fertilising material and apply it in the best manner possible. The tree responds to kindly treatment with the utmost readiness, and will bear almost any illusage and yet recover and yield good crops. Ten cwts. to the acre, or nearly one pound per tree of prepared coffee, used formerly to be considered a good crop, but now, owing to the ravages of the "leaf disease," it is regarded as extraordinary, and half the amount only is more frequently obtained. At present prices this represents about $25 l$. per acre with which to pay all the working expenses of the estate. Amongst these is the cost of Tamil coolies from the south of India, who have to be maintained during the greater part of the year at the rate of one labourer to every acre of coffee in full bearing, their pay averaging $9 d$. per day of ten hours, viz., from 6 A.M. to 4 P.M. Besides this main charge there are artificialmanures, tools, bullock-waggons, bullocks specially kept for making manure, road-making, \&c., to be paid for, together with assessments for grant-in-aid roads, and other public purposes, so that to manage an estate well is a very expensive affair, and can only be done where there is a large incoming of gross profits.

No mention has yet been made as to how the land is acquired by the planter and under what title it is held. When the English took possession of the Kandyan province in 1815 , they agreed, by a convention, to respect both the religion and the private property of the natives. This latter consisted chiefly of rice-fields, whilst the jungle-covered mountains having never been considered of any value were not claimed, and consequently passed into the hands of the British Government. As soon, then, as their value began to be appreciated for coffee cultivation, they were put up for public sale at an upset price of $5 s$. per acre, and many estates were purchased at that rate. At the present time the upset price is $I l$, and the land not unfrequently realises as much as $\mathrm{I} 5 l$. or 20 l. per acre, so prosperous has been the enterprise of late years and so great the influx of English capital. The blocks of land when put up for sale are mostly of convenient sizes--200 or 300 acres - and the competition is frequently very keen for the more suitable pieces. As none but jungle land, except in very rare instances, is planted with coffee, the forest and undergrowth have to be cleared away and the ground thoroughly opened before the plants can be put in. This is done in November or December by Kandyan woodmen, who are very skilful with the axe, and the remains of the forest having been dried by an eight or ten week's exposure to the sun during the hot season are burnt off about February. As soon as the rainy season comes, holes 18 inches square and deep are dug, and the plants, having had their rootlets carefully trimmed, are deposited in them. At this period of its formation the estate is generally quite free from weeds on account of the recent fire, and very great care is used to prevent any, especially ageratum or couch grass, getting a hold on the soil.

As to the general statistics of the enterprise I find by Mr. Ferguson's very valuable directory that there are at the present moment 257,000 acres of cultivated coffee, divided into slightly more than $\mathrm{r}, 200$ estates, and giving employment to I,050 managers and superintendents, nearly all of whom are Europeans. Some 50,000 acres of these estates are not in proper bearing, through being either too young or too old, and therefore 210,000 acres may be taken as the extent of the plantations of the island, which are accountab!e for the present year's crop (ending in September), estimated at 630,000 cwts. Last year the yie.d, with 8,000 acres less in cultivation, was 873,000 cwts.

The value of the whole plantation interest is roughly estimated at nine millions sterling of English money.

The extent of native coffee, i.e., of the gardens of the Singhalese, which are generally situated in the immediate neighbourhood of their villages, where the trees are allowed to grow as they will, is probably between 40,000 and 50,000 acres, and the average annual production may be estimated at from 140,000 to I 50,000 cwts. The value of this native property is set down roughly at three-quarters of a million sterling.

In 1849 the value of the former variety of coffee when prepared was $33 s$, and of the latter $18 s$. per cwt. At the present moment so great has been the rise in the prices of both kinds that plantation fetches as much as Ioos. and native 85 s. per cwt.

A comparison of the statistics of the coffee enterprise for the year 1852 (the earliest for which I have any reliable information) and the present year furnishes several points of interest both to the planter and the European consumer. The former was a fairly good year, better than I853, but not to compare with any of the immediately succeeding years. The latter year is distinctly a bad year, but whether exceptionally so or not is the chief point of interest and anxiety. In 1852 about 40,000 acres were under plantation cultivation, and $255,000 \mathrm{cwts}$. were produced, nearly $6 \frac{1}{2} \mathrm{cwts}$. per acre. In the present year about 257,000 acres are cultivated-one-fifth perhaps not being in full bearin?, as was probably the case in $1852-$ and 630,000 cwts. are expected to be obtained, an average of less than $2 \frac{1}{2}$ cwts. per acre. The native coffee produced in the same two years will most probably be about the same in quantity, viz., I 50,000 cwts. A fairer mode of comparison, no doubt, is that of taking the last five years, say from 1872 to 1876 inclusive, and comparing the average annual production per cultivated acre during that period with that of the five preceding years from 1867 to 187 I, for it was in 1872 that the falling-off due to the "leaf disease" began to be seriously felt. During the earlier five years the rate of production per acre was 4.6 cwts. During the later period only $2.9 \mathrm{cwts}$., a decrease of somewhat more than one-third. It may 
naturally be asked, What is the cause of this falling-off in the average production? One reason, no doubt, is that some estates are becoming old, and when an unfavourable season occurs their cultivation is temporarily unprofitable. But the main cause is most certainly the fungus (Hemileia vastatrix) on the leaves of the plant. This appeared first in 1869 , and in 1872 was recognised as a firmly-established coffee pest. It is generally admitted that the injury is caused through the weakening of the tree by the absorption of the juices of the leaf, for no plant has ever been known to be absolutely killed by the attack or even by a succession of them. The first symptom of the disease is a palish discoloration in spots or patches, easily detected when the leaf is held up to the light. These quickly assume a faint yellow colour, and presently become covered with yellow dust, which soon turns into a rich orange. These are the ripened spores of the fungus aggregated in little clusters, and attached to branching filaments, that have found their way from the air-spaces within the leaf, where they have been feeding on its juices and ruining its vitality. It is cstimated that there are sufficient of these spores on a badly diseased leaf to infect 100,000 plants, and therefore it is no wonder that the pest, when once it had come to maturity under the favourable conditions of a coffee estate, should spread in an incredibly short space of time over the whole mountain zone, and that probably within less than two years from its first appearance every coffeetree in the island had been more or less affected by it. The injury in the first instance appears to be done solely to the leaf, which, at a certain stage of the attack, dies of exhaustion, and the tree being an evergreen has to throw out another mass of foliage, which also in its turn becomes affected and dies. Consequently the strength of the plant, which ought to be spent in bearing fruit, is chiefly devoted to putting out new flushes of leaves, whilst a certain percentage of the crop that is at last ripened is found to have suffered from the general weakness of the tree. For a disease of this kind it is impossible to suggest any remedy, such as sulphuring the leaves. Imagine such an operation as sulphuring more than $250,000,000$ trees, and then only obtaining a temporary relief! Manure gives a tree strength to bear fruit as well as leaves, and therefore is the most approved of all the remedies tried as yet.

With regard to the origin of the disease, nothing is known, except that it first appeared on a new estate in Madulsima, a district in the south-east of the mountain zone, and bordering on the low country. Mr. Thwaikes, the botanist, believes that it has been introduced into the island in imported manure, which is a probable explanation of its origin, so far as Ceylon is concerned. Against this supposition, however, is to be set the fact, according to the writer's belief, that Hemileia vastatrix is found in no other country in the world except Southern India, and on no other tree except the coffee-tree. It is, therefore, possible that it may have existed in a modified form, and without attaining any great development on some of the trees in the low country jungle to the eastward, and from them may have been carried by the wind to a neighbouring coffee estate. Be this as it may, it is not now likely that its origin will ever be known, unless future research into the nature of fungi throws a light on the subject which it is impossible to anticipate. As to the future of the coffee enterprise in Ceylon, it is useless to predict. Let us hope that the same Providence which has ordained that masses of plants, animals, or men, may not be unnaturally aggregated together without some disease becoming epidemic among them, may also in this case apply the same law for the destruction of the disease itself, by developing among its countless myriads of spores a principle of death, which may cause the plague to disappear as suddenly and mysteriously as it came.

Since the above was written, the blossoming season has proved so favourable that it is estimated that the crop for the year ending September, 1877 , will exceed a million cwts, but whether the plants have suffered so seriously from the attacks of the "leaf disease" as to be unable to bring this crop to maturity time alone can prove. June, 1876

R. AEBAY

$$
\text { OUR ASTRONOMICAL COLUMN }
$$

6r CYGNI.-The following formulæ for the difference of right ascension and declination of the components of 6r Cygni are founded upon a comparison of Bessel's measures with the Königsberg Heliometer (mean epoch, I $835^{\circ} 47$ ) and Baron Dembowski's between I 871 and I875, on forty-two nights :-

$$
\begin{aligned}
& \Delta \alpha=+22 \cdot 1727+[8 \cdot 74448](t-1870) \\
& \Delta \delta=-7 \cdot 4928-\left[9^{\circ} 27780\right](t-1870)
\end{aligned}
$$

If the angles of position and distances are calculated from the differences of right ascension and declination thus obtained for the epochs of the older observations, collected by Bessel in his earlier memoir, it will be found that there remains but a very doubtful deviation from rectilinear motion. Bradley's observations, I753.8, exhibit the largest difference, $3^{\circ} 9$, but having regard to the discordance between the result from Piazzi's observations for 1806.3 and Bessel's for 1812.9 , both of which can hardly be correct, this difference is not excessive. It appears that the only suspicion of curvature of path must depend upon these early and more uncertain data, as, indeed, was inferred by Mr. Wilson, of Rugby, some time since.

TUTTLE'S COMET.--The calculations of Clausen and Tischler have placed the theory of this comet upon a very satisfactory foundation. Discovered in the first instance by Mechain, at Paris, on January 9, 1790, it was observed until February I a parabolic orbit was com. puted by the discoverer, which subsequently figured in all our catalogues, but there appears not to have been at that time any suspicion of its comparatively short period; indeed, the short extent of observation might well prevent this. On January 4,1858 , the comet was re-detected by Mr. Tuttle, of the U.S. Navy, at the Observatory of Harvard College; the first elements calculated in this year presented so great a resemblance to Mechain's for the comet of 1790 , that the identity of the bodies was immediately inferred, and successive approximations to the period of revolution by Pape and Bruhns, showed that in the sixty-eight years' interval there must have been performed several revolutions, the latter finally concluding that the comet had returned to perihelion four times since 1790 , though on every occasion it passed unobserved. Clausen (Dorpat Observations, vol. xvi.) calculated the perfurbations due to the attraction of Jupiter between $185^{8}$ and I790, and thus carrying back the elements deduced from the observations of 1858 to I 790 , found but small differences from those obtained from observation in the latter year, which difference was still further reduced after he had included the effect of Saturn's attraction from 1805 , January 30 , to 1816 , August 24 , and from I83I, July I7, to I843, October 22 . Tischler's results are published in his "Inaugural Dissertation"Ueber die Bahn von Tuttle's Comet, Königsberg, 1868. In this able investigation of the young astronomer (who unfortunately lost his life before Metz) elements founded upon the observations of $\mathrm{j} 858$ were used for the calculation of the perturbations, on the method adopted by Bessel for the comet of 1807 , from 1858 to 1844 , including the effect of Venus, the Earth, Mars, Jupiter, Saturn, and Uranus, and for all the remainder of the interval the effect of Jupiter and Saturn for every roo days. With these perturbations of the first order, the elements were found for every 6ooth day, and with these 